\title{
Tantric Nuances Arguing Gender Order in Mithila Paintings
}

\author{
Pragya Paneru*
}

\begin{abstract}
This article reviews the Tantric influence in the traditional Mithila paintings and argues how Tantra's emphasis on femininity can challenge the traditional patriarchal notion toward women in general. In doing so, firstly, the article examines the studies in Tantra and its views toward women in general. Secondly, it analyzes the studies in Mithila paintings and their connection with Tantra and the actual women context in the Maithil community. Lastly, it reviews some of the examples of Mithila paintings to study the presence of tantric symbols, as claimed by the studies in Mithila paintings, followed by a conclusion. The findings suggest that being a highly patriarchal culture, with limited authority to women even in their personal life decisions, Mithila culture yet contains seeds of resistance within itself. On the one hand, Maithil women lack the liberty of sexual expressions, decision makings, and involvement in outdoor activities as the veil in their head symbolically separates them from the rest of the society, except the traditional feminine chores. On the other hand, traditional Mithila paintings mocks the patriarchy through the feminine images and symbols as eminent cosmic power, a source of creation, and destruction. The Tantric images and signs in Mithila paintings shout out the power of femininity, challenging patriarchal beliefs of men as a center and women as a margin. This article stresses that Tantric dualism and its equal emphasis on femininity reflected in Mithila paintings can be used as a powerful religious, cultural, and artistic tool to empower women and subvert the general binary of men and women. Mithila paintings that have become a source of economic empowerment, emotional expressions, and means of awareness of women in the present-day, can also be used to harmonize the male-female tensions and as an effective religious, cultural, and artistic device to tear-off shackles of patriarchy.
\end{abstract}

Keywords: Khobar, Chaturthi, femininity, rituals, patriarchy, Tantra, empowerment (Minimize the key words to 4-5)

\section{Tantra and Femininity}

Tantra has a close connection with femininity. It is a branch in Hinduism and Buddhism where duality is accepted, and both masculine and feminine energy is

${ }^{*}$ Ms. Paneru is a Lecturer in Enlglish at Nepal Commerce Campus. She is currently in Australia for higher degree research studies. 
emphasized instead the general emphasis of masculinity over femininity. Landesman, (2008) claims that female role models were promoted in the Tantric culture in Buddhism with goddess Tara as the central figure in religion and rituals. Tantra goddess Kamakhya is regarded as a 'matrix of power' and 'mother womb,' a creative source of cosmos (Urban, 2009). One of the unique features of Tantra is its respect toward women as tantric rituals require women's presence and their active participation, which challenges the patriarchal notion of men centeredness (Biarnacki, 2007). Tantra is a practice of spiritual-attainment, transcendence, and extraordinary powers (Feuerstein, 1998). Tantric goddess is violent, dangerous, and all-powerful, who alone can engulf the hostile forces of the cosmos (Urban, 2009).

Even though Tantra is used and emphasized from different perspectives, one of the undisputable aspects of the Tantra is its pedestal positioning of the feminine power as the superior and the most esteemed. In this sense, Tantra positions women power, that is, Shakt, in an exalted position, and women are integral parts of Tantra rituals, unlike general Hindu and Buddhist traditions that put men at the center. "Central to Tantra's teachings is the concept that reality is unity, an indivisible whole. It is called Shiva-Shakti, Cosmic Consciousness" (p. 15). Mookerjee and Khanna (1977), define Tantraas the union of Shiva and His creative power, Shakhty who are "eternally conjoined" and cannot separate as a symbol of the potentiality of an individual that is integrated into the entire cosmic scheme. According to Tantra, emancipation is possible not in negation but by the experience of totality, and the totality is only possible by accepting both masculine and feminine power.

\section{Mithila Paintings and Tantric Symbols}

Mithila Paintings or Madhubani paintings are the traditional paintings done by the women in the Mithila culture. These paintings include three different types of paintings called Aripan (floor paintings), Kobhar (wall paintings), and Pata Chitra (paper painting). These paintings are traditionally made differently by different caste groups (Brahmins, Kayasthas, and Dushad) using their traditional skills and available materials. Brahmins' paintings are full of bright colors and their style is called Bharni style, Kayasthas' minutely sketch with bamboo pens with fine lines, which is called Kachni style, and Dushad's (so-called low caste people) paintings are not much colorful and made from lowly materials like cow dung and ashes. These paintings also reflect their social status, hierarchy, and traditional professions in their elegances. Studies claim that in all types of Mithila paintings Tantric logos are used, and feminine images and symbols are regarded as essential parts. This, however, indicates the dual nature of Mithila culture: flaunting of feminine power in a highly patriarchal culture. 
The inclusion of Tantric images in Mithila paintings are acknowledged by many scholars (Mookerjee \& Khanna, 1977; Subedi, 2015; Suman, 2020; Vequaud, 1977). Maithil women consciously or unconsciously brandish the Tantric way of feminine power in their paintings through the recurrent images of Tantric goddesses, geometric symbols, and male female sexual symbols as a part of tradition. Since Tantra gives equal and essential value to the existence of females as a form of Shakhty, unlike mainstream patriarchal culture prevalent in Maithil Region, the Tantric overtone in the Maithil paintings seems to celebrate the male-female union as the source of creative energy. Also, it is challenging the patriarchal tradition of Mithila culture in which women have little agency outside the household chores. The Tantric symbols of yoni and lingam are the most repeated and inevitable images in the Mithila paintings that celebrate both masculine and feminine energy and contribute to harmonizing the hierarchies of gender by giving the message of significance to both sexes.

Mithila culture has an influence of philosophy of Tantric dualism in which, perfect goal is achieved in the union of the two matters: Priority and Prussia. This union is shown in almost all types of Kobhar paintings. Even the images of a cosmic pond,' (Kamala Daha), vegetations, the deities, images of the married couples, bamboo grooves, and all other images depicted in the paintings are the effect of this union. There are different opinions about the symbolic representations of each motif among some scholars. For example, Camphol (2008) takes "bamboo as alluding to the male of phallic principle" and lotus leaves as yoni (34).Similarly, Archer (1949) claims, "the most flagrant images of bamboo trees and the ring of lotuses as fertility and male/female sexual organs. The circle represents lotus as well as the bride's sex, whereas bamboo is representative of the phallus" (28). Whereas, for Jain (2005), the 'bamboo grove' motif represents male energy but not their sexual organ and the leaves are symbols of the bride but not her genitals (55-7).Singh (2020) claims that there are multiple interpretations of symbols according to the artists. According to Singh (2020), different motifs in the form of different animals and objects are used in Kobhar paintings symbolizing different auspicious meanings such as, lotus symbolizes wealth, Fish symbolizes breeding, tortoise means copulation, snake means protection, and scorpion suggests readiness suggesting fertility and union as an important aspect of the Mithila culture. Nevertheless, it is a well-accepted fact that Mithila Paintings has a balanced representation of male and female energies.

A unique Mithila painting called Aripan uses the yantras (geometrical signs) with Tantric influence. Mookerjee and Khanna (1977) mention, "Yantras are the diagrammatic equivalent of the deity and consists of linear and spatial geometrical permutations of the deity" (p.33). In yantras, point, line, circle, triangle, and square are combined to provide static and dynamic balance. These kinds of yantras are widespread 
in Mithila paintings. We do not miss these things in any of the Mithila paintings, which prove Tantric influence and even its dominance in the Mithila paintings. Unlike the patriarchal culture that is practiced in the Maithil region, Tantrism gives more focus to the women's creativity and takes her as the source of all cosmic creations. This aspect of Mithila paintings can be used as a feminist tool to critique the pseudo-Hinduism practices and cultures, which are more tilted toward patriarchy. Regarding highly patriarchal Mithila culture, Brown (1996) comments upon rural Maithil Brahman and Kayastha women:

...observes purdha. There is an annual fair, Saurath Sabha, conducted by the Maithil Brahmans for the purpose of arranging marriages, but no woman, and certainly no potential bride, is present at this event. In 1980 I was the sole woman, among ten thousand men who had gathered to negotiate marriages for their sons and daughters. (p.720)

Brown's description of Saurath Sabha gives glimpses of how women are secluded from one of the most important decision-making meetings of their lives. The exclusion of women from such meetings and her traditional costumes, which require her to veil her head in front of the male members of the family and society, shows the patriarchal dominance in Mithila culture. Maithil women's sufferings and seclusions are also reflected in the Maithil women's folk tales practiced in the Janakpur areas (Davis, 2009), suggesting Mithila culture's male dominancy and women's sufferings in folk tales. Dahal (2018), also gives references to patriarchal pollutes in the Mithila culture where girls from a young age are cultured into a typical kind of womanhood and a practice of Dahej (dowry) from the bride's natal family as something which devalues women's self-worth. These studies show the situation of women in Mithila culture in general.

In contrast to Mithila culture's patriarchal part, Tantric inspiration in Mithila paintings enlightens another aspect of the same tradition where femininity is also equallycelebrated.Tantradenounces traditional patriarchal practices, which regards women as lowly beings. Unlike patriarchal culture, Tantra gives higher status to woman and takes female principles as the dynamic consciousness to require getting rid of the three knots: shame, hate, and fear. If we compare the Tantric philosophy with the patriarchal edge of Mithila culture, Tantrism in Mithila culture can impact both men and women in society to bring gender harmony and equality. It needs to be discussed openly and brought into the debate for that purpose. In this context, the Mithila paintings with Tantric overtone can be an instrument to uplift the women's position and status.

Mithila art's recurring motifs like sun, pond, bamboo groves, copulating parrots, snakes, mango trees, elephant, lotus flowers, fish, Shiva-Shakti union, and Naina Jogan (symbol of Tantric goddess Kamakhya) are the symbols suggesting Tantric influences. 
According to Mookerjee and Khanna (1977), in Tantra, a lotus is one of the archaic symbol, which means door, an opening game of the "womb of universe" (p. 67), unfolding of self, expanding consciousness, and also a symbol of the Sahasrara Chakra (highest human energy center on the crown) when it is put upon the head. Similarly, planetary signs and the Kali images are also important recurring images in Mithila paintings, which are equally important images in Tantric art. Planetary signs show astronomical influence in the Mithila paintings whereas, Kali is one of "the most important tantric Dasa Mahabidhyas", and an "active cosmic power of eternal time (Kala)" (p. 75). Triangles are the common Tantric symbols used in Mithila paintings, which are regarded as very auspicious. If the triangle is kept straight, with a point upward, it is regarded as mother earth, and if kept upside down, with the point downward, it is a symbol of the Yoni (vagina). Here, Yoni is not taken as a sexual organ or object like in the Western tradition, but a symbol of goddess Durga, who is the source of creative power, and who represents women in general. This celebration of the source of creativity through Yoni symbol is a very positive sensitivity toward the prominence of women in Mithila culture. The similarity of the images used in Tantra and Mithila paintings also proves the influence of Tantrism in Mithila arts.

Another scholar, Vequaud's (1977), while claiming Mithila paintings as "heavily charged with tantric symbolism" (p.17), acknowledges the importance of Tantric symbols in Mithila arts. A very prominent Maithil artist, Suman, in a personal interview, with the researcher claimed that Tantric symbols have a very long tradition, and a widespread influence of Tantra is found on a Janam Patri (a Hindu traditional way of recording birth details in the paper) in Hindu tradition. Suman accepts the Tantric mark in the Mithila paintings, and according to him, most of the women are using Tantric symbols unconsciously. He argues that Mithila culture acknowledges women in the form of Durga Puja (worship of the female goddess) in which Durga prayers are used to begin all types of ceremonies. He believes that there was an equal emphasis to both males and females in our ancient religious practices and the patriarchy was just the latter development, not a tradition. He further claims that even in the patriarchy Mithila culture has subtle rituals like Chaturthi (ritual when bride and groom are kept in Kobhar Ghar in bride's home for four days and physical intimacy is restricted), Gaur Puja (worshipping of goddess Gauri who is the wife of Lord Shiva), Bidh Kauri (a ritual when a mature woman from both bride and groom's sides takes all the responsibilities of teaching rituals, monitors the immature activities, and actively takes in charge of the safety of bride and groom during and after the marriage until the couple are mature enough) respecting the women sentiments and protecting their dignity. 
Sex education is also considered as one of the motives behind traditional Mithila arts. Especially Kobhar paintings have special significance in a culture with a tradition of child marriages. Tradition of Chaturthi in Khobar Ghar has special significance in protecting the young bride from a sudden sexual abuse as sexual intimacy in immediate days of marriage are restricted in the ritual of Chaturthi. Also, the Chuman Puja at night indicates social acceptance and preparation for a newlywed for their conjugal life. Subedi, (2015) in "Maithil Cosmos" mentions Maithil paintings' significance, in giving sex education and as a celebration of physical and spiritual union. He mentions, "Every element in Mithila painting has a deeply rooted symbolism in it focusing around passion, sex, fertility, and tantric ritual." Also, Kapadi, (2013) in his article, states that in Mithila culture, talking about "sex awareness" is not allowed, but in paintings, especially through Kobhar, symbolically, this message is given. In Kobhar, "parrot, tortoise, and fish are drawn representing love, longevity, and fertility, respectively" (p.150). The sexual symbols in Mithila paintings are not just a modern invention instead a part of Tantric influence, which has a long history back in the ancient Hindu traditions which regards the conjugal relationship as auspicious.

Being a highly patriarchal culture, and yet having the influences of Tantra and traces of rituals that protect women's sentiments and dignity, Mithila culture carries contradictions. The rituals are very thoughtful and helpful for the women in a traditional society where child marriage, unmatched marriage, and arranged marriage were on practice. Tantric symbols show men and women in the equal podium and in a way, women's agency is much more emphasized. This paper argues that a conscious use and understanding of these symbols can be used to uplift women's position and to challenge the patriarchal norms prevalent in the society.

\section{Review of some symbols in Maithil paintings}

Some Mithila paintings by both male and female artists are discussed in the section below to analyze the symbols and images presented there. Mithila paintings are traditionally Maithil women's domain, although male artists are also involved in commercial Mithila paintings in these days. Keeping this in mind, paintings by Maithil women are included more in the discussion.

The painting below belongs to Baua Devi that presents an image of lord Kamadeva (god of lust and copulation) and a pond in the right-hand side. We can also see a pair of snake copulating in the pond. The image of vegetation in the background of Kamadeva makes the picture more colorful and attractive. Kamadeva is a god of 'Kama', meaning lust, who initiates the entire organism into sexual indulgence to continue the work of creation. Even if the picture overtly does not show the female agency, the copulating snake imagery, the green pond, and the vegetation hint that 
without feminine help, the creativity is not possible. Projecting sexual intimacy in terms of the source of creation is another imperative factor of Mithila paintings that portrays sexual indulgence as a work of creation.

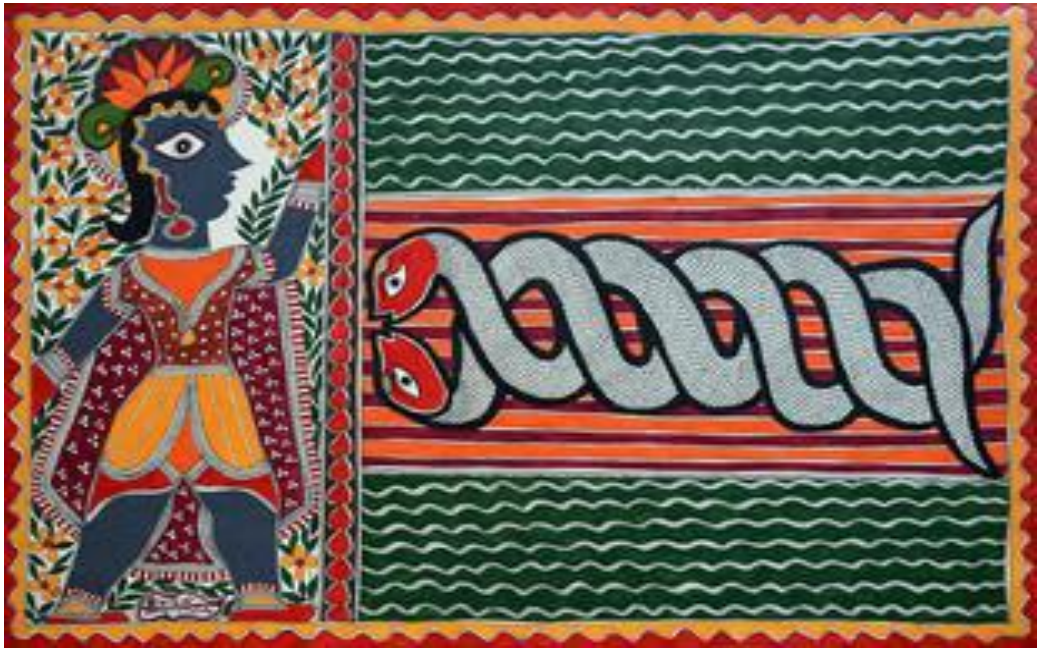

Artist: Baua Devi

Another painting by Ganga Devi, portrays one of the most important motifs and recurring images used in Kobhar painting. This painting presents Naina Jogan, an amalgamation of powerful positive as well as a negative force, which is a representative of Tantric goddess Kamakhya. Goddess Kamakhya is supposed to be originated from the falling off Satidevi's (Shiva's wife) vagina. Goddess Kamakhya is one of the most important goddesses to be worshipped in Tantra Sadhana and also one of the prominent Shakti Pith (religious place worshipped for power) of Hinduism. An image of Naina Jogan in Khobar Gharis believed to avoid the evil eyes, protect the newly-wed couples, and guard the impulsive sexual union among the couples for four days. According to Mithila culture, newly-wed couples should compulsorily observe the tradition of Chaturthi, that is, sleeping in Kobhar Ghar for four days and doing different religious prayers. The couples performing Chaturthi cannot have a sexual union. The sociological implication of this ritual is to give time and space to a newlywed bride to understand her partner and to get an emotional connection before the sexual union. In a society where most of the marriages are decided by the parents without much consultation with the brides, this ritual gives them time to understand their grooms in those initial days. And an image of Naina Jogan in Kobhar symbolizes Goddess Kamakhya, who watches the activities of the newlyweds in the Kobhar Ghar. 


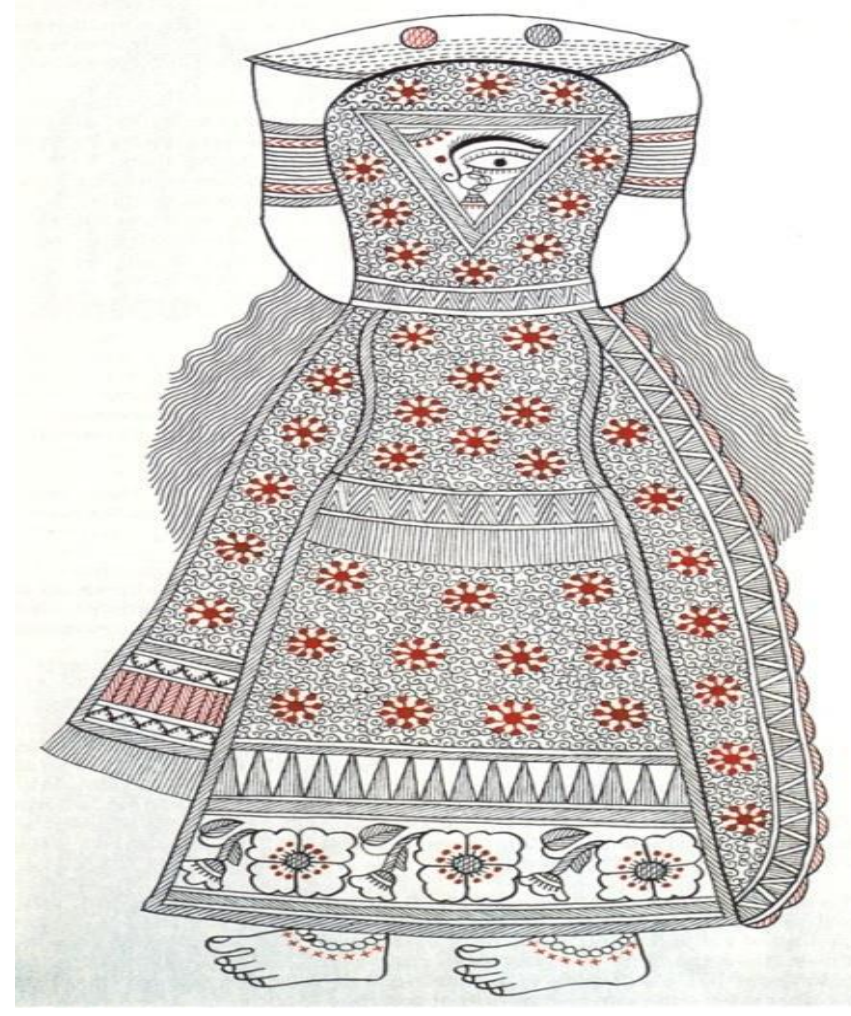

Artist: Ganga Devi, Naina Jogan 1998

Biernacki (2007), while referring to Kamakhya writes: "When we find a references in Tantric literature to rites of sexual union, we also often find reference to the worship of goddess at Kamakhya and Kamakhyaitself as the preeminent place for the practice of these rites" (5).Here, the author associates Tantric literature and the rites of union with Goddess Kamakhya, who is regarded as the goddess of Tantra. Naina Jogan in Mithila paintings is the representation of Goddess Kamakhya herself, who is used as a special motif in Kobhar paintings, which is drawn on the wall of Kobhar room where newly-weds are supposed to sleep. Naina Jogan also blesses the couples for the longevity of married life.

According to Mookerjee and Khanna (1977), Tantric imageries are grouped into four forms: "psycho-cosmic form and diagrams such as yantras and mandalas, visual representation of the subtle body or its constituents, astronomical and astrological computations and iconographic images, asanas and representational" (p.48). Maithil Aripans are a kind of blending of mandalas and yantras, where the sketches are made by the use of predominant elementary forms of Tantra itself. Aripan uses point, line, circle, triangle, square, and the lotus symbol combined, which is a floor Mithila art, unlike Kobhar. The following Aripan by Madan Kala Karn shows the Tantric influence as it uses the Tantric symbols on its form. We can see the cosmic pond, fish, and the 
lotus flower images in the painting. Images of women are depicted on both sides of the big lotus flower image. And the image dominantly uses the circular image and the triangular shapes in the painting. The triangle symbolizes the mother earth and also the primordial image of creative center or the Yoni. By depicting these images, Mithila art is celebrating the women's creative force and their value in human civilization.

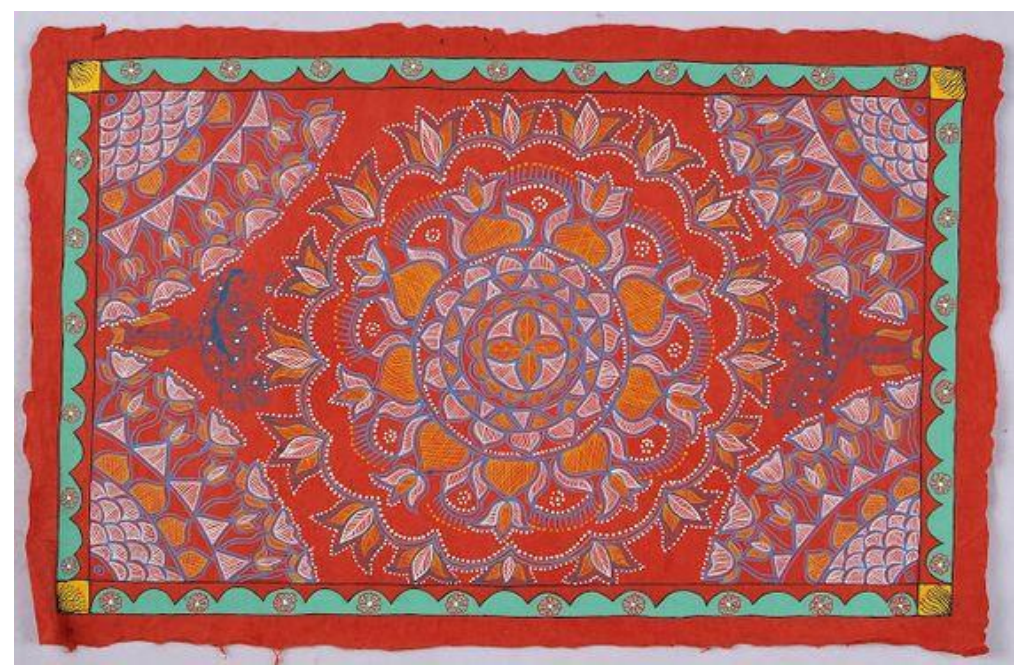

Arian by Madan Kala Karn

Another artist Aarati Kumari in her painting shows woman as Mother Nature. This sense of women as the nature or the source of creative force is the concept of tantrism. Tantrism worships women as the mother of all creativity. Mookerjee and Khanna, (1977) mark: 'The songs of Chandidas,' an offshoot of tantrism proclaims the worship of women: "You must love this woman, as no god can offer you what this woman is able to" (p.5), which proves that Tanta regards women in the high pedestal which is also depicted by this painting. 


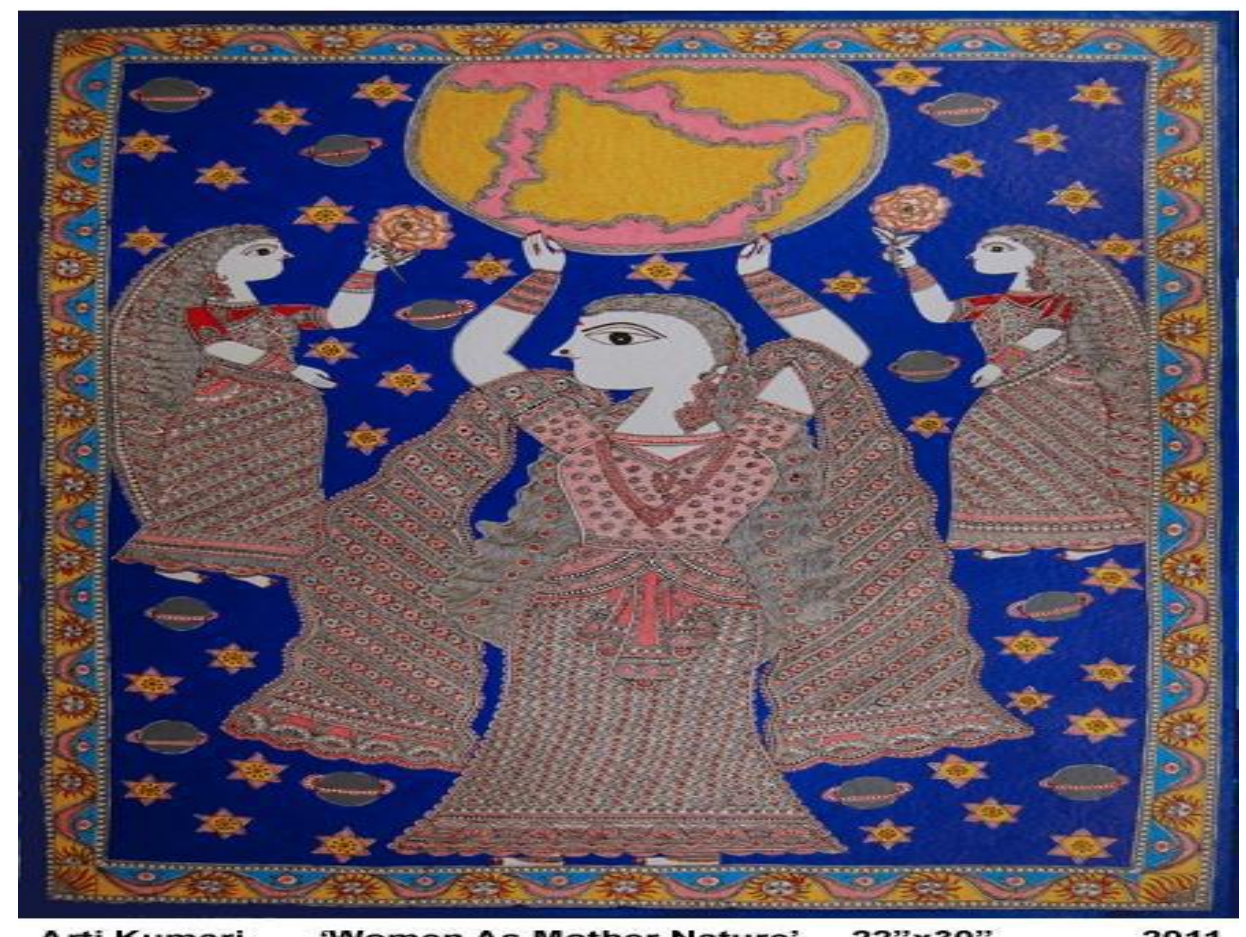

Pushpa Kumari, in her painting titled Yoni (vagina), paints the cosmic yoni of goddess Kali to highlight the power of creation within women. We can see Kali's ten hands, ten heads, and ten legs in the picture. There is an image of a baby being born from her yoni. Images of lotus petals are used in her palm and the breasts. The palms are turned outward in a blessing position symbolizing the eternal blessing of fertility and creativity. This painting very explicitly shows the value of feminine power. There is 
also a triangular Kali yantra at the vaginal edge.

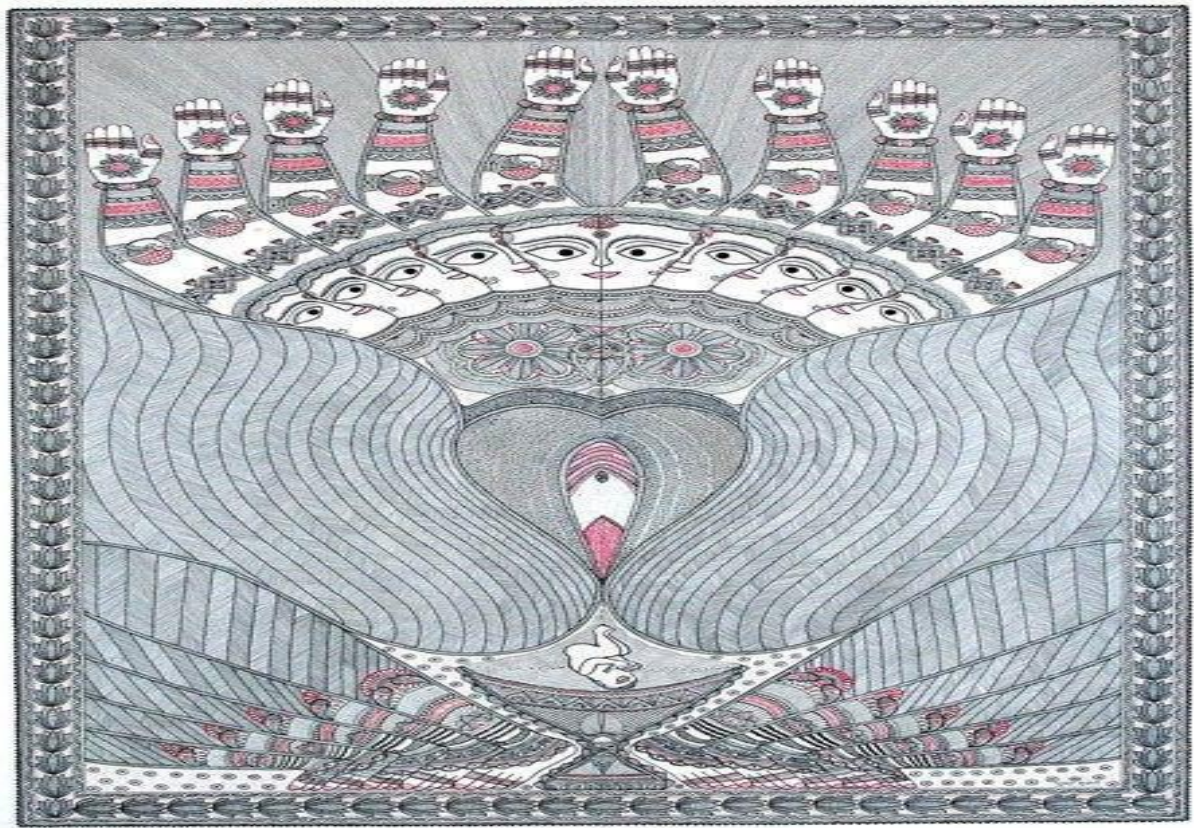

Pushpa Kumari's Yoni

It is a Tantric influence in Mithila paintings that gives space to the images of sexual copulations, lingam (symbol of the phallus), and yoni (symbol of vagina). Due to the projection of femininity and celebration of the female reproductive act, LaDuke (1981) assumes Maithili culture as a matriarchal society. Seeing the traditional Maithili paintings as dominated by women artists and women images, the author gazes at Maithili as a matriarchal society. He pens, 'When girls reach marriage age, they go to one of the regular gatherings of young men to select a mate, to whom they present a Kosher, or marriage picture. This century-old tradition continues today" (pp.9-18).Here, the author relates the tradition of Kosher painting as a matriarchal tradition, which is not valid in the context of present Maithili culture as it is loaded with highly patriarchal values, but tantrums is, of course, dominated by matriarchy. As Maithili art works are highly influenced by tantrums, in paintings, we see the domination of women representation and women power represented as untamed and all-powerful goddess Kali as the main goddess of Tanta.

We can also see contemporary influences and an accent to women empowerment in the painting of a prominent artist Rain Jha in her painting Together Tearing the Veil. In the picture, few women are tearing the veil, and coming out of it. The picture shows the maximum of its portion as an image of cover and women are there almost in the center tearing apart the veil. In this contemporary painting, we can see eyes suggesting Kali's eyes, peeping from behind of the veil. Along with Kali's eyes, there are other 
single eyes peeping from inside the veil, indicating women who are unwilling to go out of the veil. This painting encourages women to come out of the traditional norms of purda, which is one of the major obstacles in the way of women's progress and empowerment. This painting also acknowledges the patriarchal dominance in Mithila culture in the image of purda and the images of women still inside the veil.

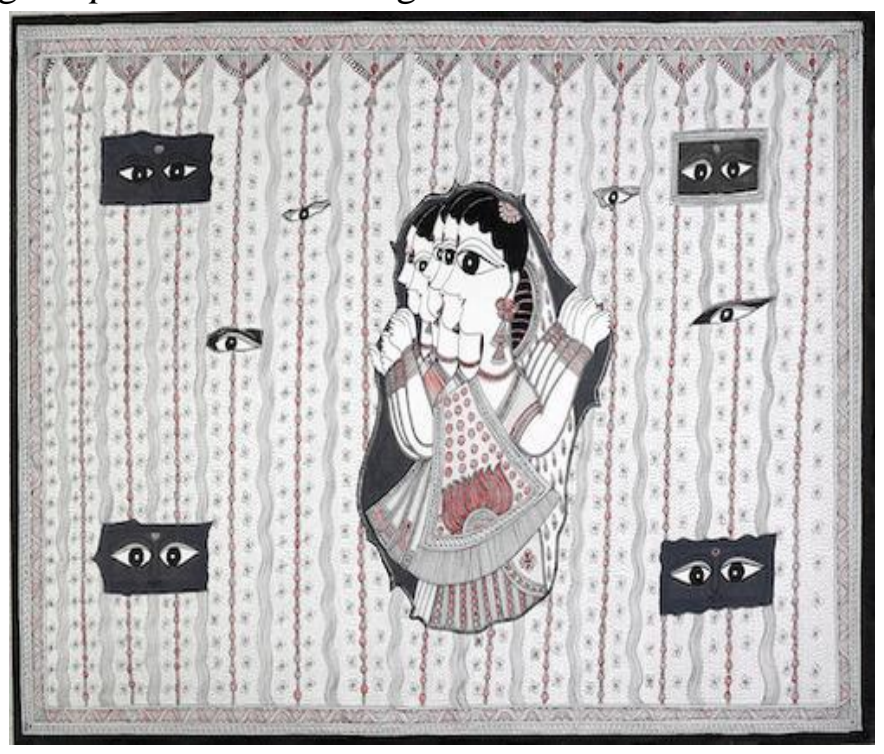

Rani Jhah Together Tearing the Veil

One of the most prominent Maithil artist, S. C. Suman, paints a harmonious social life blended with the motifs of Mithila arts. He has shown the sun symbolizing the heat or male energy, and the pond representing the feminine energy. The balance between them has created harmony among people and the prosperity of vegetations, fish, lotus, birds, fruits, flowers, and elephants. All the characters depicted in the painting seem happy, in the balance of masculine and feminine energy. Suman, in a personal interview, claims that each symbol in Mithila paintings have a purpose. The symbols and images give reference to the Tantric tone of the harmony between masculine and feminine energies. Though, Maithil women might be just drawing the paintings out of traditional rituals and might be unaware of the special significance of the symbols, the actual dynamics of these symbols cannot be eliminated. 


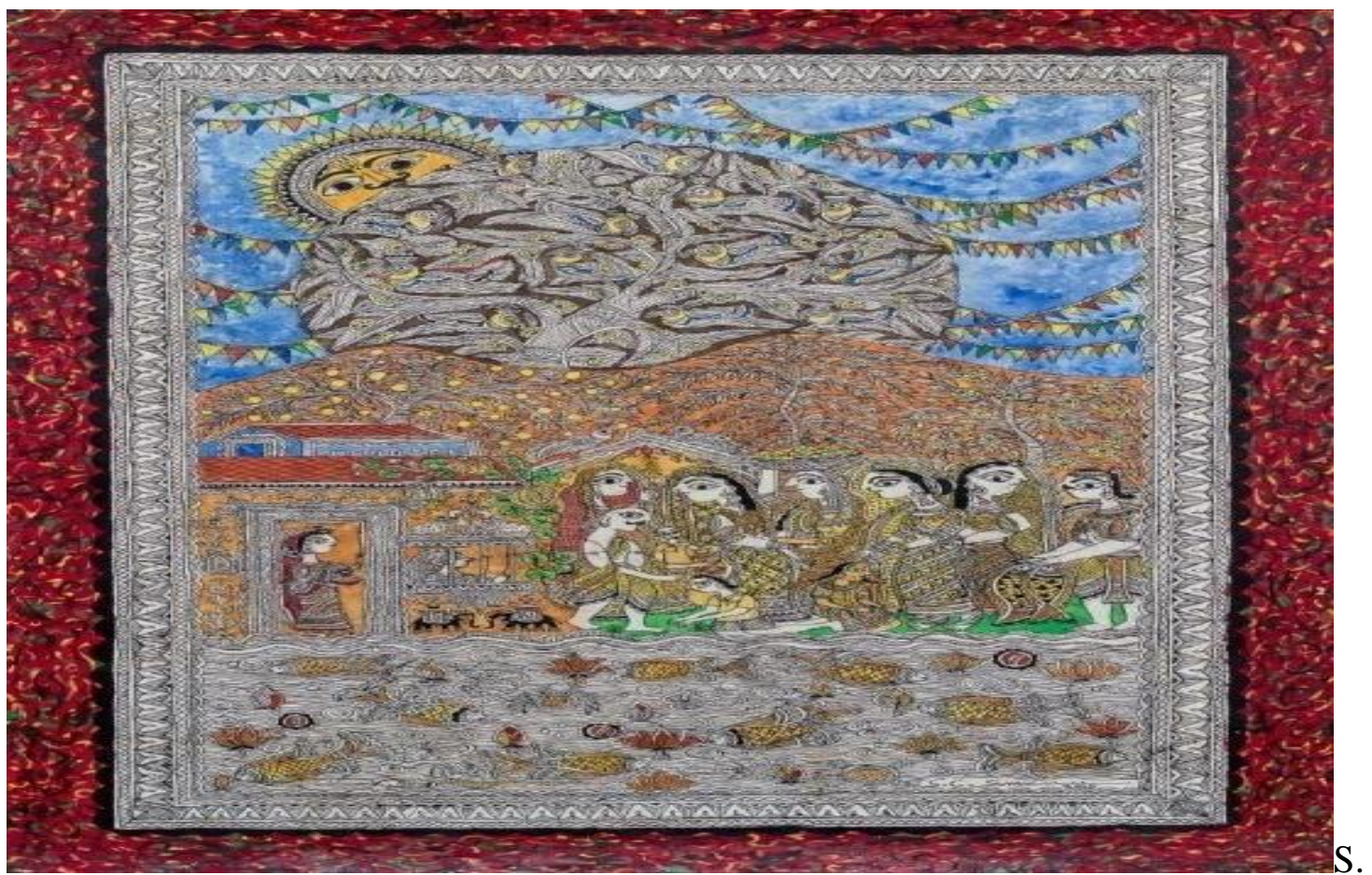

C. Sunman, Nava Barsa, 2015

These images and symbols discussed above in the paintings admit female essentiality. The male-female harmony can be seen in the images presented in different paintings by different artists. By openly discussing the implications of these religious symbols, we can promote male female parity and gender equality in the society. The conscious use of these symbols can inform equality and critique the patriarchal tendency of society. In modern days, these paintings have become a platform for women economic empowerment, a medium of women's resistance, and expression. However, the proliferation of a systemic and conscious effort in digging out the message of Tantric symbols is yet to be made.

\section{Conclusion}

The findings suggest that, Mithila paintings by almost all the artists use Tantric symbols and images as a result of Tantric influence in Mithila paintings. As Tanta is the celebration of all the aspects of life and includes women as the source of creativity, the conscious discussion of these symbols could challenge the patriarchal notions in the Maithilsociety. This article argues that if a Tantric evaluation of women as Mother Nature, source of creativity, and an essential power is discussed and proliferated consciously through paintings, the traditional patriarchal knowledge related to women could be questioned. Mithila Paintings could be used as an artistic symbol to question 
the superstitious patriarchal culture specifically in Mithila, and generally all over Nepal where female-fetus killing is still prevalent (Lamichhane et al., 2015).

A society, where maximum people are under the influence of Hindu religion, regard son as a light of their generation, and daughters as someone benefiting to others (Panthhe, 2015), Tantrism can be used to harmonize the gender tensions. In my opinion, in a highly religiously stereotypical society like Mithila culture, or Nepal in general, religious and artistic motifs can be used as an effective resistance against patriarchal culture and values. Focusing upon the dualism principle of Tantra under the Hindu religion, Mithila practices of patriarchal domination can be critiqued, and gender disparity can be challenged through Mithila paintings. Tantric revival and its discussion through Mithila arts and paintings can have a groundbreaking influence on people as most of them are only the victim of biased religious and cultural knowledge regarding women.

\section{References}

Archer, W. G. (1949). Mithila painting. Marg: A Magazine of Architecture and Art, $3(3), 24-33$.

Biernacki, L. (2007). Renowned Goddess of Desire: Women, Sex, and Speech in Tanta: Oxford University Press.

Brown, C. H. (1996). Contested Meanings: Tantra and the Poetics of Maithil. American Ethnologist, 23(4), 717-737.

Campoli, A. (2008). Ritual Art of the Kingdom of Maithil. Vajra Publications.

Dahal, K. B. (2018). Becoming Bonafide Woman. Journal of National Development, 31(1), 161-171.

Davis, C. V. (2009). Talking tools, suffering servants, and defecating men: the power of storytelling in Maithil women's tales. Journal of American folklore, 267-296.

Devi, B. (year not accessed). Kamadeva. [a picture of Kamadeva with other motifs].

Devi, G. (1998). Naina Jogan. [a paintion of traditional Maithil motif as a representative of a tantric goddess, Kamakhyadevi)

Feuerstein, G. (1998). Tantra: The path of ecstasy: Shambhala Publications.

Jain, J. (2005). Women Artists of Rural India. Women of India: Colonial and PostColonial Periods, edited by Bharati Ray, Centre of Studies in Civilizations, 501523.

Jhah, R. (year). Together Tearing the Veil. [a painting depicting Maithil women's effort to come out from purda]

Kapadi, R. (2013). Maithil Lokchitrama Nepali Sanskritiko Chintan. Mirmire, 42(320), 147-152.

Karn, M. K. (year). Aripan. [a traditional floor Maithil Art] 
Kumari, A. (2011). Woman as Mother Nature. [a painting showing women as nature]

Kumari, P. (year not accessed). Yoni. [a painting of cosmic vagina as a symbol of creativity]

LaDuke, B. (1981). Traditional women artists in Borneo, Indonesia and India. Woman's Art Journal, 2(1), 17-20.

Lamichhane, P., Harken, T., Puri, M., Darney, P. D., Blum, M., Harper, C. C., \& Henderson, J. T. (2011). Sex-selective abortion in Nepal: a qualitative study of health workers' perspectives. Women's Health Issues, 21(3), S37-S41.

Landesman, S. S. (2008). Goddess Tārā: silence and secrecy on the path to enlightenment. Journal of Feminist Studies in Religion, 24(1), 44-59.

Mookerjee, A. \& Khanna. M. (1977). The Tantric Way: Art. Science. Ritual. United States: Thames and Hudson Ltd.

Panthhe, K. P. (2015). Gender difference in rural urban education in Nepal. European Journal of Educational Sciences, 2(2), 61-79.

Singh, S. K. (2020). Central Motifs in Kohbar Murals. International Journal of English: Literature, Language \& Skills.

Singh, S. K. (2020). Folk Culture Rootedness in the Paintings of Maithili. ISSN 22780742, www.ijells. com.

Subedi, A. (2013). "Suman's Maithil Cosmos." Mithila Cosmos: Circumambulating the Tree of Life, edited by Subodh Chandra Das, pp. undated.

Suman, S. C. (2015). Nava Barsa. [a painting reflecting the celebration of a new year]

Suman, S.C. (2020, September 8). Personal Interview. [Personal Interview]

Urban, H. B. (2009). The power of Tantra: Religion, sexuality and the politics of South Asian studies: Bloomsbury Publishing.

Vequaud, Y. (1977). The Women Painters of Maithil: Ceremonial Paintings from an Ancient Kingdom. Thames and Hudson.

LOI: I hereby declare that this is my original work and it is not published anywhere. 